\title{
WHEN BRIGHT LINES BREAK DOWN: LIMITING NEW YORK V. BELTON
}

\section{DAVID M. SilK $\dagger$}

Fourth amendment ${ }^{1}$ jurisprudence has been characterized as a tension between the privacy rights of individuals and the ability of police officers to enforce the law. ${ }^{2}$ This tension has led to two methods of adjudicating disputes. ${ }^{3}$ One method is to determine the reasonableness of every search on a case-by-case basis, paying particular attention to the facts of each case. ${ }^{4}$ The second method is to create so-called "bright lines" by which police officers, courts, and individuals know exactly what may or may not be searched in any given situation. ${ }^{5}$

In the area of warrantless searches incident to arrest, the Supreme Court has established a bright line rule to govern the search of an arrestee's vehicle: "[W]hen a policeman has made a lawful custodial arrest of the occupant of an automobile, he may, as a contemporaneous incident of that arrest, search the passenger compartment of that automobile." This search may include a search of any area within the passenger compartment, as well as any containers therein. ${ }^{7}$

When the Belton rule was first announced, it was met with much scholarly criticism. ${ }^{8}$ The criticism either attacked Belton for aban-

$†$ B.S. 1985, State University of New York at Albany; J.D. Candidate 1988, University of Pennsylvania.

1 The fourth amendment to the United States Constitution reads:

The right of the people to be secure in their persons, houses, papers, and effects, against unreasonable searches and seizures, shall not be violated, and no Warrants shall issue, but upon probable cause, supported by Oath or affirmation, and particularly describing the place to be searched, and the persons or things to be seized.

U.S. Consr. amend. IV. (1964).

2 See Packer, Two Models of the Criminal Process, 113 U. PA. L. Rev. 1, 9-23

${ }^{3}$ See Amsterdam, Perspectives on the Fourth Amendment, 58 MinN. L. Rev. 349,370 (1974).

- See, e.g., Go-Bart Importing Co. v. United States, 282 U.S. 344, 357 (1931) ("There is no formula for the determination of reasonableness. Each case is to be decided on its own facts and circumstances.").

s See, e.g., United States v. Robinson, 414 U.S. 218, 235 (1973) ("We do not think the long line of authorities of this Court ... requires such a case-by-case determination.").

- New York v. Belton, 453 U.S. 454, 460 (1981) (footnotes omitted).

7 See id.

${ }^{8}$ See Alschuler, Bright Line Fever and the Fourth Amendment, 45 U. PrTT. L. 
doning the theoretical underpinnings of the search incident to arrest exception to the fourth amendment's warrant requirement or predicted that the bright line would fade by its own logic.

This Gomment examines, retrospectively, the effect of New York $v$. Belton. ${ }^{*}$ The first section explains the search incident to arrest exception, the development of bright line rules governing the adjudication of fourth amendment disputes, and the role that Belton has played in relation to these. The second section demonstrates, through an analysis of subsequent case law, that most courts have been able to discern a bright line applicable to searches of automobiles incident to the arrest of an occupant. However, courts have not been able to rely on Belton in adjudicating disputes concerning searches incident to the arrest of a person who has recently exited an automobile, and have not been able to confine Belton to the automobile context for which it was designed. Finally, this Comment suggests that a narrow interpretation of the $\mathrm{Bel}$ ton rule is the only interpretation that enables both courts and police to benefit from the bright line rule and at the same time protect the constitutional rights of arrestees.

\section{BACKGROUND}

\section{A. The Search Incident to Arrest Exception}

The Supreme Court has long recognized an exception to the warrant requirement for searches incident to arrest. ${ }^{10}$ Over the years, however, the Court has vacillated over both the permissible scope of the search and the rationale behind the exception. In Carroll v. United States, ${ }^{11}$ the Court's dicta indicated that the scope of this type of search included the person and whatever items were in her control. ${ }^{12}$ Later, in Agnello $v$. United States, ${ }^{13}$ the scope was expanded to include both the person and the place where the arrest was made. ${ }^{14}$ In the early cases, the Court justified the search as an "undoubted" right of the govern-

Rev. 227, 231 (1984); LaFave, The Fourth Amendment in an Imperfect World: On Drawing "Bright Lines" and Good Faith, 43 U. PrTT. L. Rev. 307, 325 (1982); Note, Robbins and Belton-Inconsistency and Confusion Continue to Reign Supreme in the Area of Warrantless Vehicle Searches, 19 Hous. L. Rev. 527, 548 (1982).

9453 U.S. 454 (1981).

10 See United States v. Lefkowitz, 285 U.S. 452, 453 (1932); Marron v. United States, 275 U.S. 192, 199 (1927); Agnello v. United States, 269 U.S. 20, 30 (1925); Carroll v. United States, 267 U.S. 132, 158 (1924).

1267 U.S. 132 (1924).

12 See id. at 158.

13269 U.S. 20 (1925).

14 See id. at 30 . 
ment incident to arrest. ${ }^{15}$ In later cases, broad searches were justified by the incident of the arrest itself; an arrestee's expectation of privacy was considered to be so diminished by the arrest that the additional invasion of a search was considered minimal. ${ }^{16}$

While the Court permitted some broad searches as incident to arrest, it rejected others as unreasonable. ${ }^{17}$ These latter cases were distinguished by the Court on the basis of whether or not an offense was actually being committed in the presence of the arresting officers. Thus, a broad search would be allowed only if the arresting officer actually saw the commission of an offense. ${ }^{18}$ In one of these cases, United States v. Lefkowitz, ${ }^{19}$ the Court fashioned a rule to enforce its dicta that "[a]n arrest may not be used as a pretext to search for evidence."2o

The Court also relied on the existence of the warrant process to invalidate broad searches incident to arrest. Where the arresting officer could have, but did not, obtain a search warrant, the Court suppressed evidence as the fruit of an illegal search. ${ }^{21}$ This approach, however, was later flatly rejected in United States $v$. Rabinowitz, ${ }^{22}$ in which the Court ruled that the test should not be whether the officers could have obtained a warrant, but whether the search was reasonable. ${ }^{23}$

Thus, by 1969 , the Court was faced with competing scopes and rationales for the search incident to arrest exception. One approach allowed broad searches based on the minimal additional invasion that was caused by a search incident to arrest. ${ }^{24} \mathrm{~A}$ second approach relied on the warrant requirement and a prohibition against pretextual searches to limit the scope of the search to the area within the arrestee's control. $^{28}$ Faced with this conflict, the Court granted certiorari to decide Chimel v. California. ${ }^{28}$

The defendant in Chimel was arrested in the entrance to his home. Incident to the arrest, the police searched the entire three-bedroom

15 See id.; United States v. Rabinowitz, 339 U.S. 56, 60 (1950), overruled by Chimel v. California, 395 U.S. 752,768 (1969).

18 See Chimel, 395 U.S. at 776 (White, J., dissenting).

17 See, e.g., United States v. Lefkowitz, 285 U.S. 452, 464-67 (1932) (ruling unreasonable a warrantless search pursuant to a valid arrest with the sole purpose of collecting evidence of the alleged crime).

18 See id. at 463.

19285 U.S. 452 (1932).

20 Id. at 467.

21 See Trupiano v. United States, 334 U.S. 699, 705-06 (1948), overruled by United States v. Rabinowitz, 339 U.S. 56, 66 (1950).

22339 U.S. 56 (1950).

${ }^{23}$ See Rabinowitz, 339 U.S. at 66.

24 See Chimel v. California, 395 U.S. 752, 776 (1969) (White, J., dissenting).

${ }^{25}$ See Lefkowitz, 285 U.S. at 467.

${ }^{26} 395$ U.S. 752 (1969). 
house, including the attic, garage, and workshop. ${ }^{27}$ After reviewing the history of the search incident to arrest exception, the Supreme Court held that the search was unreasonable. ${ }^{28}$

Quoting from Terry $v$. Ohio, ${ }^{29}$ the Court noted that "[ $\left.\mathrm{t}\right]$ he scope of [a] search must be 'strictly tied to and justified by' the circumstances which rendered its initiation permissible." cumstance was the need to preserve the safety of both the police and evidence:

When an arrest is made, it is reasonable ... to search the person arrested in order to remove any weapons that the latter might seek to use in order to resist arrest or effect his escape. Otherwise, the officer's safety might well be endangered and the arrest itself frustrated. In addition, it is entirely reasonable for the arresting officer to search for and seize any evidence on the arrestee's person in order to prevent its concealment or destruction. And the area into which an arrestee might reach in order to grab a weapon or evidentiary item must, of course, be governed by a like rule. ${ }^{31}$

The Court then announced the Chimel rule allowing, incident to arrest, "a search of the arrestee's person and the area "within his immediate control'-construing that phrase to mean the area from within which he might gain possession of a weapon or destructible evidence."32

Thus, Justice Stewart's majority opinion rejected both the notion that 'it is 'reasonable' to search a man's house when he is arrested in it"3s and the possibility that a search incident to arrest justified a search of the entire room in which the arrest took place. ${ }^{34}$ Rather, the search was justified only by the need to protect police officers and preserve evidence and was limited to the arrestee and her "grabbing area." The Court did not abandon its practice of determining the reasonableness of each search upon the facts of each case; it established a rule by which to measure reasonableness.

27 See id. at 754.

${ }^{28}$ See id. at 768 .

29392 U.S. 1 (1969).

so Chimel, 395 U.S. at 762 (quoting Terry, 392 U.S. at 19).

31 Id. at $762-63$.

32 Id.

s3 Id. at 764-65.

st See id. at 766 . 


\section{B. The Development of Bright Line Rules}

Bright line rules of adjudication are not unique to the fourth amendment, and were not unheard of before Chimel. ${ }^{35}$ They are most useful when a clear standard is necessary to delineate the limits of lawful action or to allocate liability. In the context of the fourth amendment, bright line rules enumerate a certain boundary beyond which police conduct is unacceptable.

Chimel was decided in 1969 , one year after Terry, at a time when the United States was experiencing social upheaval and questioning the role of police in society. ${ }^{36}$ Indeed, the Terry opinion itself reflected a concern within the legal community about the risk of police interference with liberty and personal security ${ }^{37}$ Legal scholars responded to this societal upheaval by looking to the fourth amendment as a means to restrict discretionary police conduct. ${ }^{38}$ Some commentators viewed the

35 In the area of tort law, for example, Justice Holmes created the "stop and look" rule of Baltimore \& O.R.R. v. Goodman, 275 U.S. 66 (1927), which required travelers to exit their vehicles at railroad crossings in order to avoid contributory negligence in railroad accidents, observing that "when the standard [of conduct] is clear it should be laid down once and for all by the Courts." Id. at 70 .

Six years later, in Pokora v. Wabash Ry., 292 U.S. 98 (1934), Justice Cardozo noted the ineffectiveness of the Goodman rule and limited it to its facts. Because actually stopping and exiting one's vehicle was an "uncommon precaution," even after Justice Holmes announced his rule, it could not be used as a standard for liability. Thus, in tort litigation, the reasonableness test prevailed over the bright line test and railroad accidents were once again judged according to the specific facts of each case. Id. at 10406 .

${ }^{36}$ See, e.g., J. Michener, Kent State: What Happened and Why? (1970) (discussing social tension and student protests concerning the presence and role of police on campus).

s7 See Terry, 392 U.S. at 11-16 \& nn. 9, 11 (noting tensions between police and communities and discussing specific police tactics).

ss Referring to the potential for injustice in allowing police great discretion over search and seizure decisions and to studies demonstrating this discretion, Professor Amsterdam suggested that the police be required to follow clear-cut rules regarding search and seizure. He believed that these rules, promulgated by either local police or legislatures, and subject to judicial review, would serve several purposes. First, rules would "provide a pervasive safeguard against arbitrary searches and seizures." Second, rules could be developed in a manner that was comprehensible to police, and thus would be followed by police. Third, a system of rules would require that police acted pursuant thereto, and would prevent prosecutors from attempting to create doctrines by which to justify police actions. Finally, rules would reduce individual police discretion in the performance of surveillance activities that are not considered within the constitutional definition of searches.

Indeed, Amsterdam believed that the best hope of assuring constitutional protections lay with the promulgation of police-made rules. Officers would be more willing to follow, and more likely to enforce, rules made by the department itself rather than rules imposed by courts. Moreover, public deliberation would lead to the development of higher quality decisions than would ad hoc decisions made by individual officers. Amsterdam, supra note 3 , at $405-28$. 
current state of search and seizure jurisprudence as too confusing to offer the police any guidance regarding the legality of a search. ${ }^{38}$ To solve the problem of having " $a$ fourth amendment with all of the character and consistency of a Rorschach blot," 40 many commentators urged that bright line rules be promulgated to guide police conduct. ${ }^{41}$

The commentators found clear-cut rules of adjudication necessary for several reasons. First, the possibility of discriminatory or arbitrary treatment of different citizens in similar situations, inherent in a system that allows great police discretion, was intolerable. Bright line rules, created by and for police, would limit police discretion and guarantee fair and equal treatment. ${ }^{42}$ Second, Supreme Court decisions that abandoned specific, articulable criteria for determining the propriety of a search left police uncertain about the proper scope of their authority. Rules would specifically delineate that scope. ${ }^{43}$ Third, lower courts needed guidance in defining what searches were reasonable in order to avoid constantly deferring to the judgment of the arresting officers, in effect allowing the police to define, ad hoc, the limits of their authority. ${ }^{44}$ Finally, the Supreme Court itself needed clear-cut rules of reasonableness in order to avoid the "fact-style" adjudication that had provided the lower courts with so little guidance. ${ }^{45}$

s9 See id. at 405 .

to Id. at 375.

11 Starting from the premise that "[t]he fourth amendment exists to control the government," Professor Dworkin argued that "[t]o effectively deter police misconduct the Court must develop inflexible categories and clear rules." Dworkin, Fact Style Adjudication and the Fourth Amendment: The Limits of Lawyering, 48 IND. L.J. 329, 344 (1973). He suggested that rules would be workable and effective in the search and seizure situation, unlike the railroad crossing situation, see supra note 35 , because police searches are not the stuff of ordinary life for most citizens. This was a context, Dworkin argued, where the ordinary conduct of citizens could not override the standard of conduct developed by the courts. See Dworkin, supra, at 365-66.

12 See supra notes 39-41 and accompanying text.

13 Judge McGowan argued that the increased participation of police in the creation of rules to guide their conduct would help ensure the conviction of guilty suspects. See McGowan, Rule-Making and the Police, 70 Mich. L. Rev. 659, 662-64 (1972). Because the police officers themselves had a greater amount of expertise in arrest situations than legislatures or judges, McGowan suggested that they be encouraged to formulate departmental rules, subject to judicial review, to govern their conduct. See id. at 664. He viewed this as a solution to both the undesirability of ad hoc decisionmaking by officers on the street and to the common complaint that police "are shackled by restrictive and unrealistic judicial mandates" in their efforts to prevent crime. Id. at 662.

14 See Amsterdam, supra note 3, at 415; McGowan, supra note 43, at 640.

15 Dworkin believed that clear-cut rules were necessary to guide the Supreme Court in its adjudication of fourth amendment disputes. He argued that principles and rules would rescue the court from making binding precedential decisions based upon fact patterns about which the Court made subjective value judgments concerning reasonableness. See Dworkin, supra note 41, at 344, 366. Rather, the Court should address itself to "the broad question of how privacy compares to order, with an eye to the 
The call for bright line rules was not ignored by the Supreme Court. The Chimel decision did not establish any per se rules about reasonableness; it merely established a guideline by which police and courts could measure the validity of a search. In the years that followed, however, several specific bright line rules were created. In United States $v$. Robinson, ${ }^{46}$ the Court upheld the validity of a search of the interior of a cigarette package discovered during the search of a person incident to his arrest. The Court held that, incident to a lawful custodial arrest for any violation, "a full search of the person is not only an exception to the warrant requirement of the Fourth Amendment, but is also a 'reasonable' search under that Amendment." ${ }^{47}$ In Gustafson $v$. Florida, ${ }^{48}$ the Court made clear that this rule applied to valid arrests made at the discretion of the officer as well as those made pursuant to department policy. ${ }^{48}$

In 1981, the Court was faced with its first opportunity to define "the area within the immediate control" of an arrestee. That case, New York $v$. Belton, ${ }^{\text {so }}$ created a per se rule governing searches of automobiles made incident to the arrest of occupants.

\section{New York v. Belton}

In Belton, state police trooper Douglas Nicot stopped a vehicle for speeding. While examining the driver's license and the registration of the car, the officer smelled the odor of burned marijuana and noticed an envelope marked "Supergold," which he suspected contained marijuana, on the floor of the car. Trooper Nicot directed the four occupants to exit the vehicle, patted each down, and instructed them to stand in separate areas of the highway. Nicot found marijuana in the envelope and arrested the occupants for possession of marijuana. $\mathrm{He}$ then searched the passenger compartment of the car and found cocaine in the zipped pocket of a black leather jacket belonging to passenger Roger Belton. ${ }^{51}$

Both the trial court and the Appellate Division of the New York State Supreme Court denied Belton's motion to suppress the cocaine, reasoning that the search was justified as incident to his lawful arrest. ${ }^{\mathbf{2}}$

development of categories and rules as specific as possible to govern fourth amendment cases .... . Id. at 366.

16414 U.S. 218 (1973).

47 Id. at 235.

18414 U.S. 260 (1973).

49 See id. at 263-65.

so 453 U.S. 454 (1981).

s1 See id. at 455-56.

${ }^{62}$ See id. at 456. 
The New York Court of Appeals reversed. Citing Chimel, the state's high court held that a warrantless search is not incident to arrest "where there is no longer any danger that the arrestee or a confederate might gain access to the article."

The United States Supreme Court reversed. Quoting Professor LaFave, the Court noted that "the protection of the Fourth . . . Amendment[] . . . 'can only be realized if the police are acting under a set of rules which, in most instances, makes it possible to reach a correct determination beforehand as to whether an invasion of privacy is justified in the interests of law enforcement." "\$54 It then noted that lower court decisions, both state and federal, were badly divided over the issue of the proper scope of a warrantless search of the interior of an automobile incident to the arrest of one of its occupants. ${ }^{58}$ The Court reasoned that if courts could not define the scope of a proper search, then individuals could not know the scope of their rights, and police could not know the limits of their authority. ${ }^{\text {s6 }}$

Hoping to remedy this situation, the Court fashioned a bright line rule allowing the contemporaneous search of the passenger compartment of a vehicle, and any open or closed containers found therein, incident to the arrest of one of its occupants. ${ }^{57}$ The announced rule was not intended to alter "the fundamental principles established in the Chimel case regarding the basic scope of searches incident to lawful custodial arrests." ${ }^{88}$ Rather, it was merely an interpretation of Chimel's requirement in the "particular and problematic context" of automobiles. ${ }^{59}$

Justice White dissented from the judgment of the Court. $\mathrm{He}$ asserted that, "[a]s to luggage, briefcases, or other containers, this seems to me an extreme extension of Chimel . . . " Jo Justice White would not allow a search of containers in the automobile absent "any suspicion whatsoever" that they contained contraband or evidence of a crime. $^{61}$ He did not, however, dissent specifically from the creation of a bright line rule.

${ }^{53}$ People v. Beiton, 50 N.Y.2d 447, 449, 407 N.E.2d 420, 421, 429 N.Y.S.2d 574, 575 (1980).

34 Belton, 453 U.S. at 458 (quoting LaFave, "Case-by-Case Adjudication" Versus "Standardized Procedures": The Robinson Dilemma, 1974 Sup. CT. REv. 127, 142).

ss See id. at 459 .

${ }^{86}$ See id. at $459-60$.

s7 See id. at 460 .

88 Id. at 460 n.3.

${ }^{80}$ Id.

${ }^{60}$ Id. at 472 (White, J., dissenting).

${ }^{61}$ Id. (White, J., dissenting). 
Justice Brennan dissented from both the judgment of the Court and the recognition of a bright line rule. He attacked the Court's "fiction-that the interior of a car is always within the immediate control of an arrestee who has recently been in the car"82 - on two grounds. First, he argued that the Court dangerously expanded the search incident to arrest requirement beyond the concerns underlying Chimel. $\mathrm{He}$ asserted that in this case, "the Court for the first time grants police officers authority to conduct a warrantless 'area' search under circumstances where there is no chance that the arrestee 'might gain possession of a weapon or destructible evidence." "Bs Second, Justice Brennan considered the announced bright line to fail on its own terms. He predicted that it would leave too many unanswered questions and provide too little guidance to police and courts in answering those questions:

Thus, although the Court concludes that a warrantless search of a car may take place even though the suspect was arrested outside the car, it does not indicate how long after the suspect's arrest that search may validly be conducted. Would a warrantless search incident to arrest be valid if conducted five minutes after the suspect left his car? Thirty minutes? Three hours? Does it matter whether the suspect is standing in close proximity to the car when the search is conducted? Does it matter whether the police formed probable cause to arrest before or after the suspect left his car? And why is the rule announced today necessarily limited to searches of cars? What if a suspect is seen walking out of a house where the police, peering in from outside, had formed probable cause to believe a crime was being committed? Could the police then arrest that suspect and enter the house to conduct a search incident to arrest? Even assuming today's rule is limited to searches of the "interior" of cars-an assumption not demanded by logic-what is meant by "interior"? Does it include locked glove compartments, the interior of door panels, or the area under the floorboards? Are special rules necessary for station wagons and hatchbacks, where the luggage compartment may be reached through the interior, or taxicabs, where a glass panel might separate the driver's compartment from the rest of the car? Are the only containers that may be searched those that are large enough to be "capable of holding another object"? Or does the new

${ }^{62}$ Id. at 466 (Brennan, J., dissenting).

es Id. at 468 (Brennan, J., dissenting) (quoting Chimel, 395 U.S. at 763). 
rule apply to any container, even if it "could hold neither a weapon nor evidence of the criminal conduct for which the suspect was arrested"? ${ }^{64}$

Justice Rehnquist concurred in the judgment of the Court but referred to his dissent in Robbins $v$. California ${ }^{65}$ for his opinion regarding warrantless searches of automobiles. In that opinion, Justice Rehnquist had argued that no bright line would suffice as a rule of fourth amendment jurisprudence and predicted that bright lines must fail: "Our entire profession is trained to attack 'bright lines' the way hounds attack foxes. Acceptance by the courts of arguments that one thing is the 'functional equivalent' of the other, for example, soon breaks down what might have been a bright line into a blurry impressionistic pattern."

Belton, therefore, was a decision relating not only to the scope of the search incident to arrest exception, but to the validity of bright line rules as well. The scholarly commentary that followed the decision attacked it on both grounds.

\section{The Post-Belton Criticism}

One complaint of the commentators was that the Belton decision abandoned the theoretical underpinnings of the search incident to arrest doctrine. "In Belton, the Court has turned its back on the logic of its earlier decision in Chimel v. California, which restricted police searches incident to arrest to the arrestee's immediate area of control." 67 The truth of this assertion is demonstrated most vividly by the implausibility of the presumption that an arrestee who is handcuffed in a patrol car could gain control of destructible evidence hidden in the glove compartment of her own vehicle. ${ }^{68}$

Professor Alschuler, eschewing bright lines in general, found the outcome of Belton particularly ill-advised. Rather than allowing the police to search the passenger compartment of every arrestee's vehicle, he would create quite the opposite rule: "[T]he occupants almost inva-

64 Id. at $469-70$ (Brennan, J., dissenting).

Bs 453 U.S. 420, 437-44 (1981) (Rehnquist, J., dissenting). Robbins was decided on the same day as Belton.

${ }^{B B}$ Id. at 443 (Rehnquist, J., dissenting). omitted).

67 The Supreme Court, 1980 Term, 95 HARv. L. Rev. 91, 260 (1981) (citation

${ }^{68}$ See Latzer, Searching Cars and Their Contents: United States v. Ross, 18 CRIM. L. Bull. 381, 397 (1982). While the presumption may be implausible, most courts that have addressed the question have considered the vehicles of arrestees in such situations to be subject to warrantless searches incident to arrest. See infra notes 90-92 and accompanying text. 
riably are removed before an automobile is searched; and once they have been removed, there is no longer much chance that they can secure weapons from the automobile or destroy evidence there."68 Thus, the more appropriate rule would be to require removal of the arrestee from the car but prohibit a search of the interior.

Other commentators accepted the result in Belton, but opposed the bright line rule. Even Professor LaFave, whose argument supporting bright line rules was quoted in the Belton decision, ${ }^{70}$ criticized its application. LaFave did not agree with Justice Brennan that the opinion left too many unanswered questions regarding the scope of the search in the interior of the car; he responded that the search should include only those areas that could be reached from inside the car. ${ }^{71} \mathrm{He}$ was, however, worried by the unanswered questions of "proximity":

$[W]$ hat the case does not reveal is whether at the time of the search the arrestee must have at least some proximity to the vehicle in the sense of being on the scene, or whether, as was customarily permitted under [Preston v. United States, ${ }^{72}$ ] the car may be searched at the scene of the arrest even after the arrestee has been taken to the station. If $\mathrm{Bel}$ ton is interpreted as having abandoned the presumably difficult-to-apply "immediate control" test of Chimel in favor of a "bright line," then the argument will certainly be made that an on-the-scene requirement is appropriate as the nearest available "bright line."73

Although LaFave was satisfied that the Belton decision provided some guidance as to timing and the physical proximity of the vehicle to the arrestee, ${ }^{74}$ other commentators were not convinced. "It is unclear whether the search-incident-to-arrest exception applies when . . the arrestee has been outside the vehicle for a considerable length of time, or when the arrestee is no longer near the vehicle."75

Additionally, some commentators predicted that neither police nor courts could draw a clear line to contain the Belton exception to searches of automobiles. One questioned how a policeman could distin-

69 Alschuler, supra note 8, at 274.

zo See Belton, 453 U.S. at 458.

71 See LaFave, supra note 8 , at 327 n.114. LaFave's approach has been followed by the courts. See infra notes 123-32 and accompanying text.

72376 U.S. 364 (1964).

73 LaFave, supra note 8, at 327 n.114.

74 See id.

${ }^{76}$ Note, Warrantless Vehicle Searches and the Fourth Amendment: The Burger Court Attacks the Exclusionary Rule, 68 CoRnel. L. REv. 105, 139 (1982)(citations omitted). 
guish between the search of a backpack on the rear seat of a car occupied only by the driver and the search of a backpack left on the ground a few feet away from a hitchhiker. ${ }^{76}$ Likewise, there were predictions that the exception would spill over to lunch boxes in factories, filing cabinets in offices, duffel bags in Winnebagos, and jackets on living room sofas. ${ }^{77}$

Finally, the Belton bright line was attacked as subject to abuse by police officers hoping to find a pretext to search a suspect's vehicle. Assuming that the police had probable cause to arrest a suspect, but no probable cause to search her vehicle, they could merely wait for the suspect to enter her car and begin to drive away. If she were arrested twenty yards down the road, the passenger compartment of her car would be subject to a warrantless search. ${ }^{78}$

In response to the Supreme Court's rule, several commentators have suggested that state courts should interpret their own state constitutions to be more restrictive of police conduct than the federal Constitution. Some suggested that the Belton rule be abandoned completely and the Chimel rule of immediate control be continued in its pre-Belton form. ${ }^{79}$ Others suggested that the rule be modified to allow only warrantless seizure of the car or the containers therein, thus prohibiting warrantless searches. ${ }^{80}$

In the six years that have passed since the Belton decision, several states have had the opportunity to evaluate the bright line rule. Most of the states that have considered the rule have accepted it; ${ }^{81}$ the others

${ }^{76}$ See Alschuler, supra note 8, at 282-83.

77 See Note, Robbins, Belton and Ross: Reconsideration of "Bright Line" Rules for Warrantless Container Searches, 31 Clev. ST. L. REv. 529, 541 \& n.83 (1982). For a discussion of how the Belton rule has been extended beyond the context of automobiles, see infra notes 148-81 and accompanying text.

${ }_{78} \mathrm{See}$ Note, supra note 77, at 558. For a discussion of pretextual use of the Belton rule in order to allow a search, see infra notes 182-96 and accompanying text.

${ }^{70}$ See, e.g., Hancock, State Court Activism and Searches Incident to Arrest, 68 VA. L. REv. 1085, 1132-36 (1982).

${ }^{80}$ See, e.g., Note, supra note 75 , at 560 .

82 See Johnson v. State, 406 So. 2d 446, 448 (Ala. Crim. App. 1981); State v. Hersch, 135 Ariz. 528, 531, 662 P.2d 1035, 1038 (1982); Baxter v. State, 274 Ark. 539, 542, 626 S.W.2d 935, 937, cert. denied, 457 U.S. 1118 (1982); People v. Henry, 631 P.2d 1122, 1128 (Colo. 1981); Traylor v. State, 458 A.2d 1170, 1173 (Del. 1983); State v. Anders, 407 So. 2d 290, 292 (Fla. Dist. Ct. App. 1981); Boyd v. State, 168 Ga. App. 246, 249, 308 S.E.2d 626, 630 (1983); State v. Calegar, 104 Idaho 526, 530, 661 P.2d 311, 315 (1983); People v. Hoskins, 101 Ill. 2d 209, 217, 461 N.E.2d 941, 945, cert. denied, 469 U.S. 840 (1984); Doe v. State, 451 N.E.2d 1096, 1098 (Ind. Ct. App. 1983); State v. Sanders, 312 N.W.2d 534, 539 (Iowa 1981); State v. White, 230 Kan. 679, 680, 640 P.2d 1231, 1232 (1982); State v. Lamare, 463 A.2d 279, 280 (Me. 1983); Farrow v. State, 68 Md. App. 519, 528, 514 A.2d 35, 39 (1986), cert. denied, 308 Md. 382, 519 A.2d 1283 (1987); People v. Miller, 128 Mich. App. 298, 305, 340 N.W.2d 858, 861 (1983), cert. denied, 466 U.S. 943 (1984); State v. Liljedahl, 327 
have either rejected or modified the Supreme Court's rule. ${ }^{82}$ One of the first states to reject the rule of New York v. Belton was New York. On remand from the Supreme Court, the New York State Court of Appeals rejected, under the state constitution, the bright line rule as a method of determining the propriety of a search. Instead, the Court relied upon the fact that Trooper Nicot could smell marijuana in the car and considered the cocaine found in Belton's jacket pocket to be the fruit of a search authorized by probable cause. ${ }^{83}$ Likewise, courts in California, Massachusetts, Oregon, and Washington have rejected or modified the Belton rule. ${ }^{84}$

N.W.2d 27, 30 (Minn. 1982); Horton v. State, 408 So. 2d 1197, 1198-99 (Miss. 1982); State v. Harvey, 648 S.W.2d 87, 88 (Mo. 1983) (en banc); State v. Roth, 213 Neb. 900, 903, 331 N.W.2d 819, 821 (1983), affd, 217 Neb. 80, 80, 348 N.W.2d 125, 125 (1984); State v. Kearney, 183 N.J. Super. 13, 20, 443 A.2d 214, 217 (1981), certif. denied, 89 N.J. 449, 446 A.2d 169 (1982); State v. Cooper, 304 N.C. 701, 705, 286 S.E.2d 102, 104 (1982); Nealy v. State, 636 P.2d 378, 381 (Okla. Crim. App. 1981); State v. Rice, 327 N.W.2d 128, 131 (S.D. 1982); State v. Cabage, 649 S.W.2d 589, 591-92 (Tenn. 1983); Alexander v. State, 629 S.W.2d 776, 778 (Tex. Ct. App. 1981); State ex rel. K.K.C., 636 P.2d 1044, 1046 (Utah 1981); State v. Phillips, 140 Vt. 210, 216, 436 A.2d 746, 749 (1981); State v. Boswell, 294 S.E.2d 287, 295 (W. Va. 1981); State v. Fry, 131 Wis. 2d 153, 168, 388 N.W.2d 565, $571-72$ (1986); Lopez v. State, 643 P.2d 682, 685 (Wyo. 1982).

${ }^{82}$ See Commonwealth v. Toole, 389 Mass. 159, 160-61, 448 N.E.2d 1264, 1266 (1983) (noting that Massachusetts statutory law places a greater restriction on police activity than does the federal Constitution); People v. Belton, 55 N.Y.2d 49, 51, 432 N.E.2d 745, 746, 447 N.Y.S.2d 873, 874 (1982) (rejecting, on remand from the Supreme Court, the Court's bright line rule); State v. Kirsch, 69 Or. App. 418, 422, 686 P.2d 446, 448 (1984) (declaring that Belton is not the law in Oregon); State v. Stroud, 106 Wash. 2d 144, 151-52, 720 P.2d 436, 440-41 (1986) (recognizing a different bright line rule than the one announced by the Supreme Court in Belton).

Some states have neither accepted nor rejected Belton. See State v. Ortiz, $67 \mathrm{Haw}$. 181,183 n.2, 683 P.2d 822, 825 n.2 (1984) (acknowledging, but declining to apply, the Belton rule). Courts in California have both accepted and rejected Belton without a clear statement of law from the state's highest court. Compare People v. Gasteiger, 180 Cal. Rptr. 704, 713-14 (Ct. App. 1982) (following Belton) with Miller v. Superior Court, 127 Cal. App. 3d 494, 506, 179 Cal. Rptr. 783, 790 (1981) (stating that Belton is not the law in California).

${ }^{83}$ See Belton, 55 N.Y.2d at 55, 432 N.E.2d. at 748,447 N.Y.S.2d at 876.

84 See supra note 82 and accompanying text.

The lack of congruence between state and federal constitutional law regarding the validity of searches gives rise to the possibility of a modern "silver platter" problem. In Elkins v. United States, 364 U.S. 206, 223-24 (1960), the United States Supreme Court held that evidence obtained by state officers in violation of the federal Constitution was not admissible in federal courts. Thus, evidence given to federal law enforcement agencies "on a silver platter" could not be used.

A modern version of this problem may be seen in the prospect of state officials obtaining evidence in violation of state law and admitting that evidence into federal courts. See, e.g., United States v. Henderson, 721 F.2d 662, 664 (9th Cir. 1983) ("Whether information secured by state officers entirely without federal involvement should be admissible notwithstanding violations of state law is a question that remains undecided."), cert. denied, 467 U.S. 1218 (1984). But see United States v. Loggins, 777 F.2d 336, 338 (6th Cir. 1985) ("The fact that Michigan law may . . . require greater 
Belton, therefore, must be evaluated on three levels. First, it must be seen in light of the reasons supporting its adoption by the Supreme Court. Second, it can be viewed as a response to the scholarly arguments in favor of clear-cut rules to guide the police and courts in administering and interpreting the fourth amendment. Third, the rule can be evaluated in terms of the dissent's and critics' dire predictions concerning its implementation.

If Belton has succeeded, it would have created a workable rule that can be relied on by both police and judges. The next section of this Comment will evaluate the ability of courts to define the scope of the rule, limit its application to factual situations similar but not identical to that in Belton, and refrain from extending its application to situations in which no automobile is involved.

\section{Belton IN THE COURTS}

New York v. Belton ${ }^{85}$ was intended to guide lower courts in the evaluation of vehicle searches incident to the arrest of a recent occupant of the vehicle. ${ }^{86}$ Criticism at the time Belton was decided suggested that lower courts would not be able to follow the Belton rule when adjudicating disputes involving automobile-related arrests, would not be able to confine the rule to automobile situations, and would allow police to use the Belton decision to create a "free search" zone under the pretext of lawful arrest. ${ }^{87}$ Subsequent case law has proven the second and third predictions to be correct. Courts have neither been able successfully to contain Belton to automobile searches nor have they been able to prevent police from using the rule as a pretext for conducting otherwise unacceptable automobile searches. ${ }^{88}$ The first prediction, however, was incorrect: the Belton rule has been a bright line standard applicable to automobiles.

protection against searches and seizures is of no avail to a defendant in a federal court, under prosecution for a federal crime."); United States v. Nelligan, 573 F.2d 251, 253 (5th Cir. 1978) ("[F]ederal law governs the admissibility of tape recordings in federal criminal cases . . . [regardless of whether] a state agent rather than a federal agent is . . . alleged to have violated the state statute." (citations omitted)); United States v. Gervasi, 562 F. Supp 632, 648, 650-51 (N.D. Ill. 1983) ("[E]vidence obtained by state officials in violation of state law [is] admissible in a federal proceeding if the evidence was not obtained in violation of federal law."). An extensive examination of this question is beyond the scope of this Comment.

ss 453 U.S. 454 (1981).

${ }^{86}$ See id. at $459-60$.

${ }_{87}$ See supra notes $67-80$ and accompanying text.

${ }^{88}$ See infra notes $148-90$ and accompanying text. 


\section{A. Automobile Searches}

\section{The Definition of "Contemporaneous"}

Critics predicted that the bright line would fade as soon as police officers attempted to carry out searches "contemporaneous" with the arrest of an occupant of a car. Professor Alschuler noted that police officers often remove an arrestee from a vehicle in order to search it properly, thus every search pursuant to Belton would "almost invariably" involve an arrestee who is not actually in the car. ${ }^{80}$ The question that courts were left to answer was how close to the car the arrestee must be standing in order for the search to retain the urgency that justifies it.

Justice Brennan's dissent provided the answer. "Under the approach taken today, the result would presumably be the same even if Officer Nicot had handcuffed Belton and his companions in the patrol car before placing them under arrest ...."90 Although Brennan did not consider this result to be desirable, many courts have in fact agreed with it as a statement of the law. These courts have interpreted Belton to mean that instead of evaluating each custodial arrest from a vehicle, a court need only find that an article was within the passenger compartment to determine that it was within an arrestee's immediate control. ${ }^{81}$ Thus, most state and federal courts have upheld the validity of the search of an automobile incident to the arrest of a recent occupant, even when the arrestee is handcuffed in the patrol car at the time of the search. $^{92}$

A few courts, however, "have read Belton more narrowly, and have found it not to apply to searches made while the defendant was arrested, handcuffed, and seated in the back seat of an [F.B.I.] agent's car without possibility of access to his own vehicle." ${ }^{\text {93 }}$ In United States

89 See Alschuler, supra note 8, at 274.

20 Belton, 453 U.S. at 468 (Brennan J., dissenting).

91 See, e.g., State v. Press, 9 Kan. App. 2d 589, 594, 685 P.2d 887, 891 (1984).

${ }_{92}$ See, e.g., United States v. Cotton, 751 F.2d 1146, 1148 (10th Cir. 1985); State v. Hersch, 135 Ariz. 528, 530-31, 662 P.2d 1035, 1037 (1983); Baxter v. State, 274 Ark. 539, 542, 626 S.W.2d 935, 936 (1982); People v. Henry, 631 P.2d 1122, 1125 (Colo. 1981); State v. Valdes, 423 So. 2d 944, 944 (Fla. Dist. Ct. App. 1982); State v. Hopkins, $163 \mathrm{Ga}$. App. 141, 141-42, 293 S.E.2d 529, 529 (1982); People v. Loftus, 111 Ill. App. 3d 978, 980, 444 N.E.2d 834, 836 (1983); Horton v. State, 408 So. 2d 1197, 1198 (Miss. 1982); State v. Miskolczi, 123 N.H. 626, 627, 465 A.2d 919, 920 (1983); State v. Cooper, 304 N.C. 701, 705-06, 286 S.E.2d 102, 105 (1982); State v. Hall, 631 S.W.2d 460, 461 (Tenn. Crim. App. 1981); State v. Phillips, 140 Vt. 210, 214-15, 436 A.2d 746, 748-49 (1981); State v. Fry, 131 Wis. 2d 153, 158, 388 N.W.2d 565,567 (1986).

${ }^{83}$ Press, 9 Kan. App. 2d at 594, 685 P.2d 887, 891 (1984); see also People v. Long, 413 Mich. 461, 472, 320 N.W.2d 866, 869 (1982) (search of as yet unarrested 
v. Farinacci-Garcia, ${ }^{94}$ the arrestee was handcuffed in the patrol car, but the search of his vehicle took place as one of the officers drove the arrestee's car away from the scene of the arrest. The District Court rejected the search as not contemporaneous to the arrest. ${ }^{95}$ Similarly, in State v. Badgett, ${ }^{98}$ the Connecticut Supreme Court found that a search lost its characterization as contemporaneous the moment that the defendant left the scene in a patrol car. ${ }^{97}$ Thus, even under the narrow interpretation, a search will be considered contemporaneous so long as both the arrestee and the car are still at the scene of the arrest.

Some cases, however, have extended Belton even beyond the majority interpretation that allows searches of automobiles while the arrestee is handcuffed in the patrol car. For example, in Smith $v$. United States, ${ }^{98}$ the arresting officer drove the defendant in the patrol car from the scene of the investigatory stop to the scene of the crime, a few blocks away. Another officer drove the defendant's car to the scene of the crime. After the victims identified the defendant as the perpetrator of the crime, he was formally arrested, and the police searched the vehicle. The Appellate Court for the District of Columbia upheld the search as contemporaneous to the arrest under Belton.$^{98}$ Likewise, in State $v$. Blair, ${ }^{100}$ the defendants were arrested on the highway for passing counterfeit currency, and one defendant was allowed to drive the car to the police station while the other defendant was taken there in the police cruiser. The defendants' car was not searched at the scene of the arrest but was instead searched at the station. The court upheld the search as reasonable: "[The defendants] were under a lawful custodial arrest at the time of search. We do not think the fact the car was searched after [one defendant] drove it to the station rather than being searched on the roadside makes Belton inapplicable to this case."101

The Blair type of interpretation demonstrates the danger of the Belton decision: it is extremely difficult to limit it to the context in which it was decided. Because the Blair court could perceive no logical

defendant's car was unjustified because he was "under the control" of police while it was being conducted).

24 551 F. Supp. 465 (D.P.R. 1982).

os See id. at 471.

90200 Conn. 412, 512 A.2d 160, cert. denied, 107 S. Ct. 423 (1986).

87 See id. at 428,512 A.2d at 169.

88435 A.2d 1066 (D.C. 1981), cert. denied, 455 U.S. 950 (1982).

${ }^{90}$ See $i d$. at 1069.

100632 S.W.2d 567 (Tenn. Crim. App. 1982).

101 Id. at 569; see also State v. Calegar, 104 Idaho 526, 530, 661 P.2d 311, 315 (1983) (upholding a station house search of a suitcase because the suitcase could have been, but was not, searched at the scene under Belton); State v. Helfrich, 33 Wash. App. 338, 340, 656 P.2d 506, 508 (1982) (upholding a search of a vehicle made after the arresting officer drove it, with the arrestee's permission, to the station house). 
distinction between the exigencies present when a defendant is handcuffed in a patrol car and her vehicle is searched at the scene and those present when a defendant is handcuffed at the station after driving there in her vehicle, it blurred the bright line in order to encompass the latter situation. Although one situation may arguably be the "functional equivalent"102 of the other, the courts must follow a clear definition of what is a valid search incident to arrest. If the Court refuses to limit the Belton rule, its extension to tenuously related fact patterns will cause courts to admit evidence that could not be admitted under Chimel.

\section{The Definition of "Recent"}

The degree to which a search is contemporaneous with arrest is not the only temporal relationship that courts were left to interpret when implementing the Belton decision. The second relationship relates to how recently an arrestee must have been an occupant of the vehicle in order to allow a vehicle search. In this context, lower courts have been able neither to rely on the logic of the Supreme Court nor to come to a consensus of their own.

The Belton case involved the arrest of four people who were in the vehicle at the time of the arrest. ${ }^{103}$ In its decision, the Court held that "when a policeman has made a lawful custodial arrest of the occupant of an automobile, he may . . . search the passenger compartment."104 This holding has left lower courts with no guidance in cases in which the arrestee was not arrested in her car, when probable cause for the arrest was formed after the defendant exited her car, or when the defendant purposely exited and locked her car before the police could approach it.

It is clear that where a defendant has been outside of the vehicle for several hours before her arrest, Belton does not authorize a search of the vehicle. ${ }^{105}$ It should be equally clear that Belton does not apply

${ }^{102}$ Cf. Robbins v. California, 453 U.S. 420, 443 (1981) (Rehnquist, J., dissenting) (arguing that by accepting the concept of functional equivalence, courts are turning clear distinctions into gray uncertainties).

${ }^{103}$ See Belton, 453 U.S. 454, 455-56 (1981).

104 Id. at 460 (footnotes omitted) (emphasis added).

${ }^{105}$ See State v. Vanderhorst, 419 So. 2d 762, 764 (Fla. Dist. Ct. App. 1982) (Belton does not authorize a search where the defendant had been outside of his car for two and one-half hours before the arrest.); see also Gauldin v. State, 683 S.W.2d 411, 413-14 (Tex. Crim. App. 1984) (en banc) (Belton does not authorize a search where the defendant had been out of his vehicle for over an hour and had been arrested inside a bar and brought outside to the parking lot.); State v. Christensen, 676 P.2d 408, 411 (Utah 1984) (Belton does not authorize a search of a defendant's vehicle executed before defendant was on the scene.). 
when the defendant is arrested inside a building and the car is outside. Indeed, the Criminal Appeals Court of Texas has so held. ${ }^{108}$ However, the same court that year refused to grant a petition for appellate review where a lower court upheld the search of a defendant's vehicle as contemporaneous to his arrest inside a nearby building. The vehicle was twenty to thirty feet away from the building at the time of the arrest, and the only appellate judge to speak on the matter found no probable cause for the search. ${ }^{10 z}$

The most difficult question in this area is whether a search is valid as incident to arrest when the defendants exit and walk away from their vehicle before the police approach it. The Ninth Gircuit has strictly interpreted the bright line rationale of Belton. ${ }^{108}$ Reasoning that the Supreme Court stretched the Chimel ${ }^{\mathbf{1 0 9}}$ standard only to a specifically limited extent, and that allowing any search beyond that extent would create additional uncertainties, the Ninth Gircuit has refused to extend Belton beyond the factual situation of a search of the passenger compartment of a car when an occupant is arrested. ${ }^{110}$ Thus, when the arrestee is a recent occupant of an automobile, but was arrested after exiting the automobile, the Ninth Gircuit will not allow a Belton search of containers removed from the vehicle prior to the arrest. For example, in United States $v$. Vaughan, ${ }^{111}$ two men were arrested, pursuant to a warrant, after they exited the car. Vaughan also exited the car, carrying his briefcase, but was not immediately arrested. Although ordered by the police to "freeze," he started to walk away, still carrying the briefcase. The police then detained Vaughan, searched his briefcase, and discovered incriminating evidence. ${ }^{112}$ Because neither Vaughan nor his briefcase were in the car at the time of the arrest, the search of Vaughan's briefcase was not covered by Belton as a search incident to his arrest, and the court excluded the evidence. ${ }^{113}$

Other courts disagree. In People $v$. Ragland, ${ }^{114}$ the defendant testified that after being pulled over by the police, he stopped his car, immediately exited the vehicle, and locked the door behind him. $\mathrm{He}$ was outside the vehicle when he was arrested for driving without a

100 See Gauldin, 683 S.W.2d at 414.

${ }^{107}$ See Jenkins v. State, 689 S.W.2d 216, 218 (Tex. Crim. App. 1984) (en banc) (Teague, J., dissenting).

${ }_{108}$ See United States v. Vaughan, 718 F.2d 332, 333 (9th Cir. 1983).

109 Chimel v. Galifornia, 395 U.S. 752 (1969).

110 See Vaughan, 718 F.2d at 333-34.

111718 F.2d 332 (9th Cir. 1983).

112 See id. at 333.

11 See id. at 334-36.

114149 Mich. App. 277, 385 N.W.2d 772 (1986). 
license and initially refused to give his keys to the arresting officer. The officer searched the defendant, took the keys, and then searched the car. ${ }^{115}$ The court did not make a finding regarding the truth of the defendant's assertion that he was outside of the locked vehicle at the time of the arrest; rather, it considered the defendant's own version of the facts to be within the scope of the Belton rule. Relying on the Supreme Court's attempt to articulate "an objective test based on proximity in time and space of the search to the arrest,"116 the Court of Appeals of Michigan upheld the search as a valid search incident to arrest.

In Ragland, the police stopped the defendant for driving erratically; they did not have any reason to arrest him until they determined that he was driving without a license. Thus, probable cause was established after he exited his car. In People $v$. Miller, ${ }^{117}$ however, the police had sufficient cause for an investigatory stop after observing the defendants engaging in suspicious behavior late at night. When the police drove up behind the defendants' vehicle, the defendants exited and began walking in opposite directions. The officers instructed the defendants to return to the vicinity of the car, arrested them after observing a handgun in plain view in the car, and then searched the car incident to the arrest. The Michigan Court of Appeals upheld the propriety of the search under Belton. ${ }^{118}$

Likewise, in State $v$. McClendon, ${ }^{119}$ the District Court of Appeals of Florida relied on the Supreme Court's attempt to set forth a "straightforward, workable rule" in upholding the validity of a warrantless search of an arrestee's truck. ${ }^{120}$ In McClendon, however, the defendant was not arrested in his truck. Instead, he was apprehended twenty to thirty feet away, inside a service station. An Arkansas state police officer had acted on information from a Florida sheriff's office that the defendant would be at a certain location at a specific time. After following the defendant in his truck to the service station where he was expected to stop, the police officer noticed that McGlendon had exited the vehicle and attempted to place a telephone call. McClendon was arrested about three minutes after he entered the service station. ${ }^{121}$ The Florida court noted the Supreme Court's desire to eliminate the

115 See id. at 280,385 N.W.2d at 773.

${ }^{116}$ Id. at 282,385 N.W.2d at 774.

117128 Mich. App. 298, 340 N.W.2d 858 (1983) (per curiam), cert. denied, 466

U.S. 943 (1984).

118 See id. at 299-305, 340 N.W.2d at 859-61.

119490 So. 2d 1308 (Fla. Dist. Ct. App. 1986) (per curiam), rev. denied, 500 So.

2d 544 (Fla. 1986).

120 See id. at 1309.

121 See id. at 1308-09. 
need for case-by-case evaluation of whether the interior of an automobile is subject to the search incident to arrest exception and reasoned that distinguishing between arrests of persons who have recently vacated a car and persons who are inside a car would "severely diminish the purpose of the Belton decision."122

These decisions, of course, demonstrate a fundamental failure of the Belton rule. Different courts have used the reasoning of the Belton decision - the need to create a workable bright line rule-to find support for directly conflicting results. In this area, Belton fails to guide police conduct, fails to provide citizens with an idea of the scope of their rights, and fails to ensure consistent results.

Belton may be seen as a decision that allows a search of the passenger compartment contemporaneous to the arrest of a passenger because weapons or evidence are always accessible to arrestees and are therefore always within the Chimel grabbing area. Conversely, it may be seen as a decision that per se allows such searches because of the difficulty for police and courts of making the factual determination about when the contents of an automobile are accessible to arrestees. The implausibility of an arrestee breaking loose of her restraints and gaining access to evidence while she is locked in the back seat of a patrol car demonstrates that the former rationale cannot be the basis for the Belton decision. It is evident that not all searches authorized by Belton will be searches of areas that an arrestee can reach. Thus, it is simply a bright line, created in order to guide police and courts in making swift, simple, and consistent decisions. This must be seen as the rationale behind Belton.

There are several ways to define recency of occupancy that protect the bright line rule. Courts might restrict permissible searches to only those incident to arrests of persons who are actually in vehicles. Thus, a search would not be valid under Belton if the sole occupant of a vehicle was pulled over on the road, exited the vehicle, closed and locked the door, and then was arrested by the police officer. The arrestee could not gain access to weapons or destructible evidence contained in the vehicle and the officer could not perform a warrantless search without probable cause. The officer would be able to perform a Belton search, however, if the arrestee were not the sole occupant of the car and her companions remained inside the car. In such a situation, the officer could presume that the companions might reach for weapons or evidence and thus the search would be valid. This definition would protect both the underlying interests of the search incident to arrest exception

${ }^{122}$ Id. at 1310. 
and individual privacy interests.

A second option that would protect the bright line would be to allow a search of a vehicle only if the officer had probable cause to arrest while the defendant was in the vehicle. If an officer detained a vehicle pursuant to an arrest warrant or after a high speed chase, she would be able to search the vehicle regardless of whether the defendant ran from the car after being stopped. This option, however, merely changes the decision that the officer must make from whether an arrestee could reach evidence to whether probable cause existed before or after the arrestee exited the vehicle. In difficult cases, it would not be a simple factual determination that could guide officers and courts in their enforcement and administration of the law.

Only the first definition protects the bright line of the Belton case, protects the law enforcement interests underlying Chimel, and adheres to the fourth amendment's prohibition of unreasonable searches. It is, therefore, the best choice for this situation. Courts should uphold Belton searches only when the defendant is arrested while she, or a companion, is actually in the car.

\section{Scope of the Search}

Most courts have not found it difficult to determine the proper scope of the search of the passenger compartment of the car. Professor LaFave accurately predicted that this would not be an unanswerable question. ${ }^{123} \mathrm{He}$ suggested that all areas that could be reached from inside the car would be subject to the search incident to arrest exception but areas that could only be reached if the passenger exited the car would not. ${ }^{124}$

Thus, courts have found that a Belton search may include the glove compartment, ${ }^{126}$ hatchback, ${ }^{126}$ front seat, ${ }^{127}$ console, ${ }^{128}$ floor areas under the floor mats, ${ }^{129}$ and any containers brought out of the vehicle by the arrestee. ${ }^{130} \mathrm{~A}$ search may not include the area behind the door panel that cannot be reached without removing the rear seat of the

123 See LaFave, supra note 8, at 327.

124 See id. at 327 n.114.

${ }^{125}$ See State v. Bell, 195 N.J. Super. 49, 53, 58, 477 A.2d 1272, 1274, 1277 (App. Div. 1984).

${ }^{128}$ See United States v. Russell, 670 F.2d 323, 327 (D.C. Cir.), cert. denied, 457

U.S. 1108 (1982).

127 See United States v. Enriquez, 675 F.2d 98, 99 (5th Cir. 1982) (per curiam).

128 See United States v. Henry, 763 F.2d 329, 331 (8th Cir. 1985).

128 See Thomas v. State, 415 So. 2d 1246, 1248-49 (Ala. Crim. App. 1982).

130 See State v. Evans, 181 N.J. Super. 455, 461, 438 A.2d 340, 343 (App. Div. 1981). 
car. ${ }^{131}$ In addition, if the hatchback is inaccessible from the interior of the car, it cannot be searched under Belton. ${ }^{\mathbf{1 3 2}}$

A more difficult question for the courts has been the validity of a search of a passenger in the same car as the arrestee. In State $v$. $P e c k,{ }^{133}$ drugs were discovered on the person of a passenger in a car in which the driver was arrested for driving without a license. The majority of the North Carolina Supreme Court admitted the evidence based on a Terry ${ }^{134}$ stop rationale: "a reasonably prudent man in the circumstances would be warranted in the belief that his safety or that of others was in danger."138 In a concurring opinion, Justice Mitchell noted that he would rest the decision on both a Terry stop and a search incident to arrest rationale. He argued that, pursuant to arrest of the driver, the officer could have conducted a thorough search of any packages or clothing in the vehicle, including those belonging to the passenger:

To hold that Belton would not also authorize at least a "frisk" or "pat down" of a passenger in the same automobile would seem to me to create an anomaly in the law of search and seizure and draw the sort of fine distinction far more useful to students in a classroom than to law enforcement officers conducting searches of automobiles on our public streets at night. ${ }^{136}$

Some courts have, however, drawn such distinctions. Both the Sixth and Ninth Circuits have refused to allow a Belton search of passengers who were not arrested but who were riding in the car with the arrestee. In Vaughan, the defendant was a passenger in a car in which two other occupants were arrested pursuant to warrants. The officers had neither a warrant nor probable cause for Vaughan's arrest. ${ }^{\mathbf{1 3 7}} \mathrm{Re}$ lying on Ybarra $v$. Illinois, ${ }^{138}$ the Ninth Circuit noted that "[ $\left.t\right]$ he fact that he was in the company of persons for whom a warrant had been issued does not constitute probable cause." ${ }^{\text {"139 }}$ Thus, although the of-

131 See State v. Cuellar, 211 N.J. Super. 299, 303-04, 511 A.2d 745, 748 (Law Div.), affd per curiam, 216 N.J. Super. 249, 523 A.2d 662 (App. Div. 1986).

${ }_{132}$ See State v. Berrios, 478 So. 2d 890, 891 (Fla. Dist. Ct. App. 1985) (per curiam).

${ }_{133} 305$ N.C. 734,291 S.E.2d 637 (1982).

184 Terry v. Ohio, 392 U.S. 1, 30 (1968) (allowing a limited search, based on less than probable cause, of the clothing of persons that a police officer believes to be armed and dangerous).

${ }_{13 s}$ Peck, 305 N.C. at 742,291 S.E.2d at 642 (quoting Terry, 392 U.S. at 27).

${ }^{138} I d$. at 743-44, 291 S.E.2d at 643 (Mitchell, J., concurring).

197 See Vaughan, 718 F.2d at 334.

138444 U.S. 85 (1979).

139 Vaughan, 718 F.2d at 334 n.5. 
ficers could prevent Vaughan from walking away, they could not search him. The court would, however, allow a limited Terry stop after Vaughan twice tried to walk away. ${ }^{140}$

The Sixth Circuit would not even allow a Terry stop in the typical search incident to arrest situation. In United States $v$. Bell, ${ }^{141}$ the court declined to adopt an "automatic companion" rule, which would allow the search of a passenger: "[W]e do not believe that the Terry requirement of reasonable suspicion under the circumstances . . . has been eroded to the point that an individual may be frisked based upon nothing more than an unfortunate choice of associates."142

Thus, the permissible scope of an automobile search does extend to any containers, locked or unlocked, that are in an area of the vehicle that is accessible from inside the passenger compartment. However, at least when the arrest is made pursuant to a warrant, Belton has not been interpreted to allow a search of a companion who is also a passenger in the car if there is no independent cause to arrest or search that passenger.

\section{The "Bright Line"}

Many courts have demonstrated that it is possible to apply the Belton bright line in a workable manner that eliminates case-by-case adjudication of automobile searches made incident to arrest. Additionally, most courts have recognized a distinction between searches that remain within the Belton rule and searches that cause the bright line to break down.

However, some courts have failed to recognize the importance of the bright line in the Belton decision and have extended Belton-type searches to other situations. For instance, in one case the court upheld a Belton-type search at the station house after an arrest. The Tennessee Court of Criminal Appeals stated that "[w]e do not think the fact [that] the car was searched after [being driven] to the station rather than being searched on the roadside makes Belton inapplicable to this case."14s Indeed, the Supreme Court itself has noted, in the context of the "automobile exception" to the warrant requirement, that allowing a search at the station house may provide even greater protection for officers and evidence because it will eliminate the dangers inherent in a late night

140 See id. at 335-36.

141762 F.2d 495 (6th Cir.), cert. denied, 106 S. Ct. 155 (1985).

142 Id. at 499.

${ }^{143}$ State v. Blair, 632 S.W.2d 567, 569 (Tenn. Crim. App. 1982); see also supra note 101 (citing cases addressing station house searches). 
roadside search. ${ }^{144}$ However, courts that extend Belton beyond "contemporaneous" searches fail to recognize and adhere to the rationale for a Belton-type search.

The reason that vehicle searches that take place while the arrestee is locked in the patrol car can be considered contemporaneous to the arrest is completely utilitarian. Police officers need clear-cut rules. ${ }^{145}$ No one would argue that all arrestees are likely to free themselves from their restraints, enter their own vehicles, and gain control of weapons or destructible evidence. The argument that allows a search made while the arrestee is in the patrol car is that the patrol car is the nearest bright line. If, however, the utilitarian rationale of Belton fails, there is no reason to retain the rule. Thus, extending these rules to include searches beyond those made at the scene of the arrest both weakens the bright line rule and serves as an argument for overruling Belton.

If the standard conduct of police reveals that a contemporaneous search of the automobile at the scene of the arrest is not a practical alternative, the rule should be replaced. Courts must retain the Belton bright line to allow contemporaneous searches when both the defendant and the vehicle are at the scene of the arrest. When the vehicle is brought to the station house, it should not be searched incident to arrest. If police have probable cause to search a vehicle, it may be searched under United States $v$. Ross. ${ }^{146}$ If the jurisdiction has inventory regulations, it may be searched under South Dakota v. Opperman. ${ }^{147}$ But stretching the Belton rule to allow any vehicle search regardless of the fact that it is not contemporaneous eviscerates both the rule itself and the fourth amendment prohibition of unreasonable searches.

\section{B. The Belton Stretch: Using the Belton Rule to Authorize Searches Outside of the Automobile Context}

In footnote three of the Belton opinion, Justice Stewart emphasized that "[o]ur holding today does no more than determine the meaning of Chimel's principles in this particular and problematic context. It in no way alters the fundamental principles established in the Chimel

\footnotetext{
144 See Chambers v. Maroney, 399 U.S. 42,52 n.10 (1970).

245 See Belton, 453 U.S. at 458 (quoting Dunaway v. New York, 442 U.S. 200, 213-14 (1979)).

146456 U.S. 798, 825 (1982) ("If probable cause justifies the search of a lawfully stopped vehicle, it justifies the search of every part of the vehicle and its contents that may conceal the object of the search.").

${ }_{147} 428$ U.S. 364, 372 (1976) ("II]nventories [of automobiles made] pursuant to standard police procedures are reasonable.").
} 
case regarding the basic scope of searches incident to lawful custodial arrests."148 Courts, however, as predicted by the post-Belton criticism, ${ }^{149}$ have not been able to confine the decision to the automobile context. Prosecutors have attempted, often successfully, to rely on Belton to justify what would otherwise be unconstitutional warrantless searches in situations in which no automobiles are involved.

Perhaps the most justifiable of these extensions is the inclusion of searches of the passenger compartment of airplanes. ${ }^{150}$ Because the "court can see no difference between the exigent circumstances of a car and an airplane," the Belton rule has been held applicable to airplanes by at least two courts. ${ }^{151}$ This extension, however, is merely symptomatic of the difficulty courts have had in confining the decision to the context for which it was designed. Because courts are often hesitant to see incriminating evidence excluded because of poor police work, they are willing to stretch an exception to the warrant requirement so that it covers the search at hand. ${ }^{152}$

The most egregious extension of the Belton rule has come from the Fourth Gircuit. First, in United States v. Litman, ${ }^{153}$ the Fourth Gircuit interpreted Belton and Chimel to allow, after an arrest, the contemporaneous search of a bag that was "within the area in which the defendant might have reached ...."164 In Litman, the bag that was searched was sitting at the defendant's feet and would therefore have been subject to a search based on the Chimel standard. ${ }^{155}$ In United States $v$. Porter, ${ }^{158}$ however, the court upheld a search of a bag that was merely "within arm's reach" of the arrestee. ${ }^{157}$ There was no indication that it was within the immediate control of the arrestee; rather, " $[t]$ here was no possibility that the arresting officer would be endangering himself or risking the loss of evidence by deferring a search of the

148 Belton, 453 U.S. at 460 n.3.

149 See supra notes 67-80 and accompanying text.

180 Although the cases did not rely on the need for clear-cut rules to guide police when searching airplanes incident to arrest, it is arguable that such a rule would easily be applicable to small private planes. A rule could be recognized that allows per se searches of six- or eight-seat passenger planes incident to the arrest of an occupant. However, a rule allowing the search of an entire jumbo jetliner incident to the arrest of one of the dozens of passengers on board would obviously violate the Chimel standard.

151 See United States v. Rollins, 699 F.2d 530, 534 (11th Cir.), cert. denied, 464 U.S. 933 (1983); United States v. Thomas, 536 F. Supp. 736, 743 (M.D. Ala. 1982). ${ }_{182}$ See Bernardi, The Exclusionary Rule: Is a Good Faith Standard Needed to Preserve a Liberal Interpretation of the Fourth Amendment?, 30 DE PAUL L. REv. $51,82(1980)$.

163739 F.2d 137 (4th Cir. 1984).

161 Id. at 139.

Is5 See id. at 138-39.

158738 F.2d 622 (4th Cir.), cert. denied, 469 U.S. 983 (1984).

${ }^{167}$ Id. at 624 . 
bag until a warrant had been obtained."158 The court interpreted $\mathrm{Bel}$ ton to establish a " "bright-line' rule that a lawful custodial arrest justifies a contemporaneous search without a warrant of the person arrested and the immediately surrounding area." ${ }^{159}$ With the Porter decision, the court extended the bright line from searches incident to arrests of occupants of automobiles to searches resulting from Terry stops at airports. ${ }^{160}$

Moreover, in the same year, the same court indicated that there was absolutely no limit to the Belton rule by extending it to searches incident to the arrest of an occupant of a hotel room. In United States v. Silva, ${ }^{161}$ the court upheld the seizure of weapons from a locked, zippered bag as incident to the arrest of the defendant. At the time of the search, both of the arrestees were handcuffed with their hands behind their backs, and were sitting on the motel room bed. The key to the locked bag was in defendant Silva's pocket, and the police officer had to remove the key from the pocket in order to unlock and search the bag. ${ }^{162}$ Relying on Belton and Porter, the court held that since the bag "was in the immediately surrounding area" it could be searched pursuant to the incident to arrest exception. ${ }^{163}$

The Eighth Circuit has also relied on Belton to uphold a search of a hotel room incident to the arrest of an occupant. In United States $v$. Palumbo, ${ }^{164}$ police officers seized cocaine that had been taped behind a dresser drawer. Although the record is unclear concerning whether the arrestee was handcuffed at the time of the search, the majority did not believe that such a factual finding was necessary: "[A]ccessibility . . . is not the benchmark. The question is whether the cocaine was in the area within the immediate control of the arrestee within the meaning of Chimel v. California."16s Citing Belton, but ignoring the fact that Belton was confined to the "particular and problematic context" of automobiles, ${ }^{168}$ the court held that the rule defining the permitted search area "is not constrained because the arrestee is unlikely at the time of the arrest to actually reach into that area." 167 Thus, the majority used Belton to remove any probability requirement from Chimel in

${ }^{168}$ Id. at 629 (Murnaghan, J., dissenting).

${ }^{159}$ Id. at 627 (Murnaghan, J., dissenting) (citations omitted) (emphasis added). 176-77.

260 For further discussion of the facts of Porter, see infra text accompanying notes

${ }_{181} 745$ F.2d 840 (4th Cir. 1984), cert. denied, 470 U.S. 1031 (1985).

162 See id. at 843,847 .

${ }^{163}$ Id. at 847.

164735 F.2d 1095 (8th Cir.), cert. denied, 469 U.S. 934 (1984).

1es Id. at 1097.

${ }^{186}$ Belton, 453 U.S. at 460 n.3.

167 Palumbo, 735 F.2d at 1097 (citing Belton, 453 U.S. at 459-60). 
a context beyond that of the automobile search. ${ }^{168}$ Indeed, this court allowed the bright line from Belton to creep into a hotel room, an area generally granted protection similar to that given the home. ${ }^{169}$

Not all courts, however, are so willing to eviscerate the distinction between the bright line rule that applies to automobiles, and a factual finding of "immediate control" that is required elsewhere. In contrast to Porter, the Court of Appeals of North Carolina specifically "decline[d] to extend the 'bright-line' Belton approach to arrests outside the automobile context." 170 In State v. Thomas, as in Porter, the defendant was detained as a result of a Terry stop in an airport. Incident to his arrest, the agents searched his locked suitcase, which was large and cumbersome. ${ }^{171}$ The court, following United States $v$. Chadwick, ${ }^{172}$ found the search to be unconstitutional. Because luggage has a primary purpose of being a depository for personal effects, it does not have the same reduced expectation of privacy that an automobile has, and expectations of privacy are thus greater in luggage than in automobiles. Relying on footnote three of the Belton opinion, the court ruled that the Belton approach "is properly confined to the automobile context."173

The State of Maryland has also rejected an extension of the Belton doctrine. In Stackhouse $v$. State, ${ }^{174}$ the state argued that the search of an attic, executed after the defendant had been removed from the attic, arrested, and handcuffed on the floor below, should be encompassed within a broad reading of Belton. The Maryland Court of Appeals declined to read Belton so broadly as to extend to searches of a private home. ${ }^{178}$

Thus, the application of the Belton decision to situations not involving automobiles, like its application when a defendant is arrested after exiting a car, has yielded conflicting results. In both Thomas and Porter, the defendants were stopped and questioned in airports. Both possessed airplane tickets with incorrect names and were asked to accompany an investigator to an office. Both were arrested after indicat-

168 See also United States v. Wiga, 662 F.2d 1325, 1332-33 (9th Cir. 1981) (allowing a "protective sweep" search of a mobile motor home incident to the arrest of its driver), cert. denied, 456 U.S. 918 (1982); State v. Camp, 175 Ga. App. 591, 594, 333 S.E.2d 896, 899 (1985) (allowing a search of a motor home bedroom incident to the arrest of an occupant of another room).

168 See 1 W. LaFave, Search and Seizure $\S 2.3$ (b) (1978).

170 State v. Thomas, 81 N.C. App. 200, 213, 343 S.E.2d 588, 595 (1986).

171 See id. at 202,343 S.E.2d at $589-90$.

172433 U.S. 1 (1977).

173 Thomas, 81 N.C. App. at 213, 343 S.E.2d at 595.

174298 Md. 203, 468 A.2d 333 (1983).

175 See id. at 211, 468 A.2d at 337; see also United States v. Fleming, 677 F.2d 602, $607 \mathrm{n} .14$ (7th Cir. 1982) (noting that Belton applies only to automobile searches and not to searches on the porch of a house). 
ing that they possessed small amounts of contraband. ${ }^{176}$ In Porter, the agent searched a carry-on bag that was situated between the agent and Ms. Porter. The federal court found that Belton justified a search of packages within the immediate area. ${ }^{177}$ Judge Murnaghan's dissent noted that Belton was designed specifically for automobiles and did not apply to a search incident to a lawful arrest in a context apart from an automobile highway stop. ${ }^{178}$ This was the position adopted by the Thomas majority, which went on to note that, absent exigent circumstances, Chadwick prohibits the search of luggage or other property seized at the time of the arrest. ${ }^{179}$ Consequently, two cases with remarkably similar facts produced conflicting results.

The approach adopted by the Maryland and North Carolina courts is preferable to that of the Fourth Circuit. Allowing Belton to authorize searches at airports, hotels, or homes effectively overrules the Chimel doctrine. Chimel invalidated not only a broad search of the entire house but also a search of the entire room in which the arrestee was standing. ${ }^{180}$ An interpretation other than a strict confinement of Belton to the automobile context will reverse that result. The Belton court specifically rejected such a reversal. ${ }^{181}$

\section{Pretext Searches: The Belton "Free Search" Zone}

The risk of police or prosecutorial abuse is one of the most difficult problems accompanying the propagation of a bright line rule. The Belton rule lends itself especially to pretextual arrests leading to a search of the entire passenger compartment of the car. A police officer with reason to believe that a suspect is concealing contraband in her vehicle, but with insufficient information to form probable cause, may simply follow the suspect's car hoping to arrest her for a traffic violation. ${ }^{182}$ Likewise, an officer with an arrest warrant may wait until the suspect opens the door of her vehicle and then search the vehicle. ${ }^{183}$ Both scenarios represent attempts at an unwarranted extension of the Belton doctrine.

In State v. Roth, ${ }^{\mathbf{1 8 4}}$ plainclothes police kept a residence under sur$589-90$.

178 See Porter, 738 F.2d. at 624; Thomas, 81 N.C. App. at 202-04, 343 S.E.2d at

177 See Porter, 738 F.2d at 627.

178 See id. at 627-28 (Murnaghan, J., dissenting).

179 See Thomas, 81 N.C. App. at 209-13, 343 S.E.2d at 593-95.

180 See Chimel, 395 U.S. at 766-68.

181 See Belton, 453 U.S. at 460 n.3.

182 See Traylor v. State, 458 A.2d 1170, 1173 (Del. Super. Ct. 1983).

${ }_{183}$ See United States v. Bautista, 731 F.2d 97, 99 (1st Cir. 1984).

184213 Neb. 900, 331 N.W.2d 819 (1983). 
veillance for suspected drug sales. After the occupants left the house and drove to another home, the police enlisted the help of a uniformed officer to ticket the vehicle for a parking violation. The uniformed officer saw a marijuana cigarette in plain view in the car, waited for the suspect to reenter the vehicle, and then arrested him for possession of marijuana. After the arrest, another uniformed officer was able to join the first officer in the search of the vehicle. The Nebraska Supreme Court upheld the search as a valid search incident to arrest. ${ }^{185}$

Likewise, in Traylor $v$. State, ${ }^{188}$ police officers observed a known drug dealer sitting in a parked car. They investigated over the radio, discovered that the suspect's license had been revoked, and then waited for him to start the car. Once he started to drive, the police arrested him and searched the entire passenger compartment. ${ }^{187}$

The most obvious use of Belton as a pretext to allow a search of the entire passenger compartment is the situation when police wait until the suspect walks to and opens the door of her car before making an arrest. In United States v. Garcia, ${ }^{188}$ the police followed defendant Stephenson's car to a bar and then to an apartment where they suspected drugs were being sold. They waited for him to leave the apartment and walk to his vehicle and arrested him as he was "in or just entering his car." B89 By waiting for the arrest to take place in the car, the police could avail themselves of the Belton rule and search not only the passenger compartment but the briefcase that the police requested that Stephenson remove from the car.

This use of the Belton decision turns the search incident to arrest exception into an "arrest incident to search". exception. Rather than protecting the police officer from whatever weapons may be in the car or briefcase, and rather than thwarting an arrestee's efforts to reach destructible evidence, this situation unleashes weapons that may be concealed in the vehicle and allows, at the arresting officer's request, the defendant to have access to the briefcase. This police tactic merely allows the police to discover evidence that otherwise would be accessible only with a warrant. ${ }^{180}$

${ }^{185}$ See id. at $902-03,331$ N.W.2d at 822.

${ }^{188} 458$ A.2d 1170 (Del. Super. Ct. 1983).

187 See id. at 1173.

188785 F.2d 214 (8th Cir.), cert. denied sub nom. Barker v. United States, 106 S. Ct. 1797 (1986).

189 Id. at 225.

180 See also United States v. Bautista, 731 F.2d 97, 98-99 (1st Cir. 1984) (Police officials observed the defendant selling cocaine to an informant, watched him walk back to his car, and arrested him as he entered the car where they suspected that he was keeping cocaine, thereby opening the entire passenger compartment to a Belton search.). 
The second type of abuse is prosecutorial. The rationale for the Belton rule is that police need bright line rules to clarify the limits of their authority; officers cannot make case-by-case determinations of whether a particular search is reasonable. This precise need prompted the Supreme Court to decide that the interior of a vehicle is always within the reach of an occupant. ${ }^{191}$ Thus, when police are not aware of, and do not take advantage of, the rule, the rule cannot be said to guide their conduct. Rather, it merely serves to rescue prosecutors who are faced with cases of police misconduct.

United States $v$. Henry ${ }^{192}$ provides one such example. There, the arrest was made as the two defendants were driving away from an inn. Mistakenly believing that they saw a gun, the officers performed a preliminary search of the vehicle based on probable cause. Subsequent to the arrest, the officers obtained a warrant to search the car and discovered two thousand dollars in the console. The court refused to address the contention that the warrant was obtained improperly, holding that the search could have been executed, pursuant to Belton, incident to the arrest. ${ }^{193}$

In Henry, the court simply allowed the exception to swallow the rationale. The search occurred in 1984, three years after the Belton decision. Sufficient time had passed to allow the rule to filter through administrative levels to the officer on the street. The officers discerned no exigent circumstances that made it necessary for them to search the console incident to arrest. Indeed, by the time the search occurred, the defendants were no longer on the scene. ${ }^{194}$ Presumably, the court did not want to exclude the evidence, nor did it want to approve a good faith exception to the exclusionary rule. ${ }^{195}$ Instead, the court allowed the prosecution to avoid the fact that the warrant might have been improperly obtained by hiding behind an exception designed to protect evidence and officers. Prosecutors are expected to introduce incriminating evidence at trial. Likewise, rules should be promulgated to guide police conduct. However, accepting prosecutors' arguments that an officer could have relied on a rule designed to guide her in the conduct of her duties, when she in fact did not rely on that rule, allows prosecutors to act as "Monday morning quarterbacks" to repair blunders made

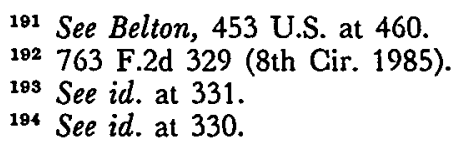

195 See, e.g., United States v. Leon, 468 U.S. 897, 919-21 (1984) (holding that the exclusionary rule should not be applied "when an officer acting with objective good faith has obtained a search warrant from a judge or magistrate and acted within its scope," even if the warrant is ultimately found to be invalid). 
by the arresting officer. If this is the purpose that the Belton rule serves, Belton should be overruled. ${ }^{196}$

\section{CONCLUSION}

Both the police and the lower courts need explicit guidance when determining the proper scope of a search. Without this guidance, the police are free to regulate themselves, and the lower courts are left to affirm the ad hoc decisions of individual officers. However, the most effective rules are not those mandated by the Supreme Court and passed down to police officers as a result of litigation but those that are implemented by police departments after careful deliberation. ${ }^{197}$

In this respect, Belton ${ }^{\mathbf{1 9 8}}$ has failed to satisfy the goals of the preBelton proponents of bright line rules. The Belton search itself was the result of an ad hoc choice made by Trooper Douglas Nicot. In deciding to search, he did not have time for careful consideration of the competing interests of law enforcement and the fourth amendment. The rule was not the product of public deliberation. Until the case was decided by the Supreme Court, neither citizens, police, nor courts knew the legal limits of a search incident to arrest. Indeed, six years after the decision, many states have not clarified this uncertainty. ${ }^{108}$

Additionally, the Belton rule itself does nothing to limit the discretion of the individual officer on the street. It merely authorizes any officer, in her own discretion, to search a vehicle contemporaneous to arrest. The only clear-cut rules that place absolute limits on police discretion are those that require all officers to comply with a certain standard. ${ }^{200}$ Those rules are best promulgated by police departments themselves, subject to judicial review. ${ }^{201}$

The fact that the decision failed to satisfy the goals of certain legal scholars, however, does not necessarily mean that the Belton rule is without merit. The Supreme Court did not consider the value of public deliberation and rulemaking when it upheld the Belton search. It

196 See also McGowan, supra note 43, at 678-79 (relating an example of a prosecutor's argument having no relationship to the actual needs of the law enforcement agency). 94.

197 See Amsterdam, supra note 3, at 417-29; McGowan, supra note 43, at 676-

188 New York v. Belton, 453 U.S. 454 (1981).

199 See supra notes 81-84 and accompanying text.

200 See, e.g., Miranda v. Arizona, 384 U.S. 436, $467-73$ (1966) (requiring that all police officers recite "Miranda" warnings before custodial interrogation).

201 See McGowan, supra note 43, at 674-75; see also United States v. Robinson, 414 U.S. 218, 220-21 \& n.1 (1973) (arrest of defendant made pursuant to departmental policy requiring arrest for operation of a motor vehicle following revocation of operator's permit). 
merely clarified-for citizens, for police, and for the courts-that the United States Constitution does not prohibit a search of the passenger compartment of an automobile contemporaneous to the arrest of an occupant. It did not prohibit local police departments from creating rules and regulations regarding the execution and scope of such a search.

In terms of the goals of the Supreme Court, the Belton rule can be seen as at least a partial success. Courts have reached a consensus on the scope of a Belton search, ${ }^{202}$ and have come to an agreement on the outer limits of the definition of "contemporaneous." Additionally, some police departments have been able to rely on this decision to guarantee that officers understand the limits of their authority. ${ }^{203}$

In other respects, the decision has failed. Because the arrest in Belton occurred while the passengers were inside the vehicle, courts have been unable to rely on the decision when the defendant was arrested outside of the car. The decision does not tell lower courts why Belton searches are valid. ${ }^{204}$ Is it because such searches are always necessarily

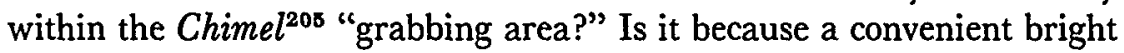
line is available? Or is it because the convenient bright line happened to be within the scope of Chimel based on the facts of one case?

Subsequent cases must be decided within the limits of both Belton and Chimel. Although the Court gave the Chimel "grabbing area" a broad reading in Belton, it reaffirmed the basic principle of the search incident to arrest exception-that only the arrestee and the area within her immediate control may be searched. ${ }^{206}$ This rationale is supplemented by a desire for bright line rules, but those rules must retain Chimel's protection. Allowing a search of the passenger compartment of a vehicle, when the occupant exited the vehicle before the arrest, does not retain that protection. Nor does allowing a vehicle search in such a situation serve the utilitarian purpose of providing a bright line. There is no guidepost, other than a clock or a yardstick, that allows a police officer to distinguish among arrestees who exited their cars one minute before arrest, five minutes before arrest, or thirty minutes before arrest.

Conversely, limiting Belton searches to automobiles that are occupied at the time of the arrest serves all of the purposes of the Chimel and Belton decisions. It provides a standard that police can follow in

${ }^{202}$ See supra notes 123-32 and accompanying text.

${ }^{203}$ Police in Florida, for example, have removed arrestees from their vehicles, handcuffed them, placed them in the back seat of the patrol car, and then searched the arrestee's vehicle. See, e.g., Padron v. State, 449 So. 2d 811, 812 (Fla. 1984); Tippins v. State, 454 So. 2d 630, 631 (Fla. Dist. Ct. App. 1984).

${ }^{204}$ See supra note 64 and accompanying text.

208 Chimel v. Galifornia, 395 U.S. 752 (1969).

208 See Belton, 453 U.S. at 460. 
making search incident to arrest decisions. It distinguishes between those cases in which an arrestee could possibly gain access to the contents of the vehicle at the time of the arrest and those in which she could not. Therefore, it protects both the privacy interests of individuals and the law enforcement interests of the government.

In the context of searches that do not involve automobiles, subsequent case law reinforces criticism of the Belton decision. The bright line is blurry to lower courts. Chimel confines searches to the area from within which an arrestee might gain control of a weapon or evidence. However, the Fourth Circuit has interpreted Belton to allow a full "area" search of the area in which the defendant is arrested, or even of the area to which the defendant has been taken after arrest. ${ }^{207}$ It is not clear, under this interpretation, exactly what type of search is prohibited by Chimel.

Glearly, in the Fourth and Eighth Circuits, Belton does not protect the privacy interests advanced by the Chimel decision. ${ }^{208}$ However, because Chimel has not been overruled, neither Belton nor Chimel can provide any clear-cut guidance to law enforcement officers. If police make warrantless "area" searches, they violate Chimel. If these cases are prosecuted, evidence discovered in the search may be introduced under an expansive reading of Belton. The only purpose that the decision can serve in that event is to allow prosecutors to correct, post hoc, the mistakes of police officers. This is an unacceptable use of Belton. ${ }^{200}$

In order to retain the contribution that Belton makes to law enforcement, the decision must be read narrowly to apply only to the specific factual situation of arrests of occupants of automobiles. Expanding the decision to cover arrests of recent evacuees of vehicles and situations not involving automobiles merely serves to blur the bright line and create an unworkable rule. While the absence of rules may create a fourth amendment akin to a "Rorschach blot," 210 the extension of rules to situations for which they were not designed creates a "blurry impressionistic pattern." 211 Neither is an acceptable model for fourth amendment jurisprudence.

${ }^{207}$ See supra notes $153-63$ and accompanying text.

208 See supra notes 153-69 and accompanying text.

209 See supra notes 191.96 and accompanying text.

210 See Amsterdam, supra note 3 , at 375.

211 Robbins v. California, 453 U.S. 420, 443 (1981) (Rehnquist, J., dissenting). 
